
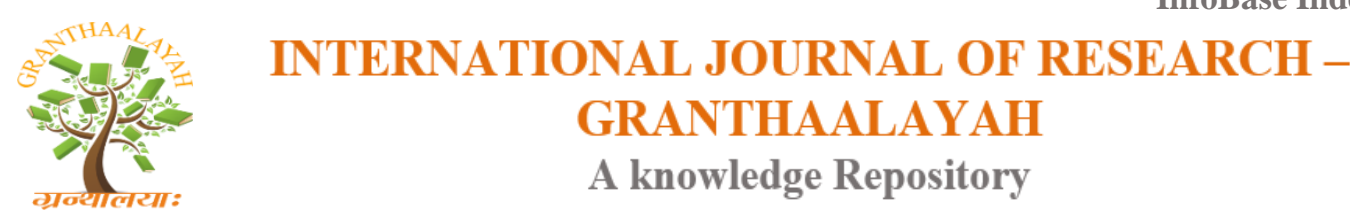

\title{
Social
}

\section{THE TRANSITION OF SINULOG DANCE FESTIVAL IN THE FACE OF MODERNIZATION}

\author{
Ersa Joy L. Ortiz ${ }^{1}$, Faith Joan P. Relampagos ${ }^{1}$, Jyn Ruehn S. Pejana ${ }^{1}$, Shene Mitchelle B. \\ Siarot $^{1}$, Nino Aaron S. Tolo ${ }^{1}$, Ruby S. Melchor, DBA ${ }^{2}$, Reynaldo B. Inocian, Ed. D. ${ }^{3}$ \\ ${ }^{1}$ Department of Tourism Management Scholars, College of Arts and Sciences, Cebu Normal \\ University, Cebu City, Philippines, 6000 \\ ${ }^{2}$ Chair, Tourism Management Department, College of Arts and Sciences, Cebu Normal \\ University, Cebu City, Philippines, 6000 \\ ${ }^{3}$ Professor IV, Social Sciences Department, College of Arts and Sciences, Cebu Normal \\ University, Cebu City, Philippines
}

DOI: https://doi.org/10.29121/granthaalayah.v5.i3.2017.1784

\begin{abstract}
This study analyzed the evolutionary transition of the Sinulog-based dance in Cebu, Philippines. It also sought to: contrast the traditional Sinug Dance and the contemporary Sinulog-based dance in terms of the dance steps, musicality, ritual, costumes, and the reason or purpose of dancing; identify the effects of the changes in the Sinulog-based dance in the tourism industry of Cebu City as a whole; generate a theory which serves as framework of the evolutionary transition of the Sinulog-based dance. A collective case study design with naturalistic observation was utilized. The transition of the traditional Sinug dance to the contemporary Sinulog dance was ignited by the change of external factors indicated in the Theory of Cultural Transition. The traditional Sinug dance was on the brink of extinction without the help of certain individuals and organization who took part in preserving this potential cultural heritage, as a response to the essentialist challenge posed by the cultural heritage advocates. The contemporary Sinulog dance transcended to a new culture after the Sinug was obliterated to a more progressivist view of change to increase tourist attraction catapulted to a more commercialized endeavor for tourism and business development opportunities.
\end{abstract}

Keywords: Sinulog Dance; Sinulog Dance Ritual; Modernization; Tradition; Culture.

Cite This Article: Ersa Joy L. Ortiz, Faith Joan P. Relampagos, Jyn Ruehn S. Pejana, Shene Mitchelle B. Siarot, Nino Aaron S. Tolo, Ruby S. Melchor, DBA, and Reynaldo B. Inocian, Ed. D.. (2017). "THE TRANSITION OF SINULOG DANCE FESTIVAL IN THE FACE OF MODERNIZATION." International Journal of Research - Granthaalayah, 5(3), 293-309. https://doi.org/10.29121/granthaalayah.v5.i3.2017.1784. 


\section{Introduction}

The modernity of the world has brought a great increase in the economy of the people due to the introduction of technology. As a result, the traditional practices shift to modernity. Transition of societies, from traditional to modern, risks the cultivation of cultural heritage. Whereas, community's practices are to be preserved through vibrant cultural heritage preservation, in order to fulfill its need for individual and social identities; yet, these practices remain difficult to achieve, when societies face a roadmap for development and progress.

Dances have been considered as one of the best avenues for self-expression and in terms of religious aspect, it becomes a part of religious worship and ritualistic practice. In the Philippines where Christianity is a dominant religion, festivals are common events to happen. As modernization is entering a new fold, the "Kaamulan (convergence) Festival" in Malaybalay, Bukidnon in Mindanao is the epitome of the identity of the local community where it has endured the tests of time, the traditional rituals and dances are still being practiced by the tribal traditional communities [1], despite the entry of modernization. "Kasanggayahan (friendship or brotherhood) Festival" in Southern Luzon portrays "Pantomina sa Tinampo (a pantomimed dancing convergence)," Bicol's regional dance, however, it imitates the styles of the "Ati-atihan (pygmy-like dance) Festival" in Kalibo, Aklan and the "Sinulog Festival" in Cebu in the Visayas, for tourism development. The cultural tradition has become a show because of the increasing number of performers and viewers, instead of an intimate tradition [2]. In these cases, the preservation of the cultural identity of a community through its dances brings unity among its people; whereas modernity contributes to the eradication of cultural identity respectively. On this note, the entry of tourists brings their respective cultures, pushes the townspeople the pressure to adapt to the global demands, providing growth in most aspects; but causing dilemmas in cultural preservation, whether to let go or to retain the traditions.

Cebu City, labeled as a "Historic City in the Central Philippines," is known for its historical landmarks and monuments as well as cultural traditions. It is a home of "Sinulog Festival" in honor to Señor Santo Niño (the Holy Child Jesus). Since its festival declaration in the 80s, it has become evident that there is a transition of the traditional Sinug dance to the grandiose Sinulog festival in contemporary times [3]. The said event has been transformed into an attraction for tourists instead of the traditional dancing in the streets by the locals, thereby making the event commercialized, instead of a celebration of a religious thanksgiving. One of the anticipated events in the entire festivities is the grandest Sinulog-based Dance competition, i.e. participated by contingents all throughout the country showing their faith to Señor Santo Niño. However, the essence of its religious festival is tinged with commercialization because of tourism promotion and attraction, though it contributes the local economy of the region, however, it nuances a twist of the Cebuano identity to blend religiosity and business to a new face.

The Sinulog-based Dance Competition is said to be based on the traditional Sinug dance-ritual. It symbolizes the goodness of Señor Santo Niño to the Cebuanos [residents of Cebu]. As the dance continues to adapt modernity, this increases risks of extinction of its cultural heritage. The experiences and knowledge of the informants of this study has been the key in unraveling a vital aspect of Cebuano Christian and indigenous cultural elements. 


\subsection{Review of Literature}

Culture is the basis of all social identity, development, and cultural heritage, i.e. the endowment that each generation receives and passes on [4]. It is a whole that completes us as humans on who we are and what we become. Dances, songs, languages, movies, rituals, festivals, foods, customs and others are just few of the representations of our culture. As an adaptive system, culture changes in the direction of equilibrium within an ecosystem, but when its balances are upset by environmental, demographic, technological, or other systemic changes, further changes ramify through an adaptive cultural system [5]. Culture is evolving at all times and it changes when it recently develops things to begin new ways of living and when new ideas take part in a culture [6].

The society undergoes transition and becomes modernized because of its normative structure, cultural traits, value system, dress patterns, and family system; which have all been strongly affected and altered due to the modern and technological world [7]. Furthermore, the intertwining of the modern and traditional is the basic characteristic of our social and cultural reality, in which modern and traditional social values are being mixed [8].

Globalization along with modernization is influencing and changing traditional cultures all around the globe. As a result, there has been an increase in the transfer of traditions and values between people and cultures. It turns out that the rapidity of cultural exchange resulting from globalization and modernization has proven to have an effect where cultural exchange and mixture has redefined many cultures rather than erased or replaced the original. Unfortunately, it appears that instead of exchange between cultures, there has been more of a one-directional transfer of ideas and values [9].

Because of the introduction of modernization in tribal villages, the tribal villages' perceptions, thoughts, food habits, daily life styles, dresses, festivals, dances, rules and rituals, the ecofriendly and nature related cultures are all deteriorating due to the impact of modernization. As modernization has entered in the tribal lifestyle, there is a chance to lose the traditions and tribal uniqueness in the long run [10].

\section{Culture through Dance}

Dance can be defined as ordered bodily movements, usually performed with music and is very complex. The rhythmic movements, steps and gestures of dance often express a religious activity [11]. Whether social, theatrical, or ritually based, dance is a form of cultural expression. Dance encapsulates, reinforces and transmits cultural traditions and values like in the visual arts: sculpture or architecture [12]. Dance is a part of religious ritual, providing a direct means of communicating with the spirits [13]. A dance dies along with its last practitioner. If communities have disappeared, grown or changed over time, so have their dances [12].

As cultural practices have become standardized, many traditional practices are abandoned. Music, dance and theatre are often key features of cultural promotion intended to attract tourists and regularly feature in the itineraries of tour operators. Although this may bring more visitors and increased revenue to a country or community and offer a window onto its culture, it may also 
result in the emergence of new ways of presenting the performing arts, which have been altered for the tourist market. While tourism can contribute to reviving traditional performing arts and give a 'market value' to intangible cultural heritage, it can also have a distorting effect, as the performances are often reduced to show adapted highlights in order to meet tourist demands. Often, traditional art forms are turned into commodities in the name of entertainment, with the loss of important forms of community expression [11].

\section{International Cultural Dances}

The multifaceted relationship of westernization, colonization, and cultural identity is an illustration of the evolution of New Dance from a colonial product into a traditional dance form. New Dance is a creation of a particular historical era, and it has been shaped by specific modernizing influences and cross-cultural exchanges. For instance, the successors of the New Dance are now leading the Korean dance community, performing both traditional dances as well as new dances based on the notion of an innovating tradition [14]. Korean dance is handed from generations with minimal influence from the outside world. Korean traditional dance is about Korean spirit and identity, not a technique for visual effects. If spirit and identity define the "Korean-ness" of Korean dance, it is necessary to examine the concepts of Korean spirit, Korean identity, and performance technique in relation to a New Dance [14].

Flamenco in its original form starts as a chant, i.e. accompanied by the rhythm, beaten out on the floor by a wooden staff or cane. The dance is an "outsider art," i.e. passed down from generations within families, reaching beyond the academic realm [15]. There has been some difficulty in determining the essence of a flamenco dance as a diverse and often mislabeled and disconnected genre [16]. Modernization is an unavoidable and undeniable factor in any traditional society. It cannot only be analyzed through its negative impacts, but it has its positive impacts too. Some of the important factors that helped to modernize the Sili dance in the Sakawa Sili tribe: change in the traditional rhythms of songs and Western fashion [17]. Moreover, adults prefer pure traditional dances and youths prefer dance mixture of current realities to which they have been exposed [18].

\section{Philippine Cultural Dances}

Most of the dances of the festivals in the Philippines have evolved through time and these have transcended a bit trendy to suit the modern time, for example: change in rhythmic patterns of song and the use of more electronic instruments instead of the traditional and indigenous instruments [17]. This is observed through the major festivals in the Philippines like the Pintados, Dinagyang, Sinulog and others.

The pantomina (pantomiming) or sinalampati (dove-like) is a courtship dance in Bicol, performed at fiestas and weddings and also danced in the streets as a highlight of the Kasanggayahan (friendship or brotherhood) Festival [19]. It has become a show instead of an intimate cultural tradition because of the large number of performers and viewers, as result of modernity and a mark of progress [20]. 
The Ati-atihan (Black-Pygmy-like) Festival could be considered the Mardi-Gras of the Philippines while countless Señor Santo Niño statues are hoisted over the parading crowds or pushed through small floats [21]. The Ati-atihan in Kalibo has already evolved into a celebration with religious undertones where anything goes as long as it's in the name of fun [22].

Leyte's Pintados-Kasadyaan (tattooed-merry-making) Festival is a gathering of fun and leisure, highlighting the Kasadya-an (merry-making) Festival of festivals of Leyte, the Ritual Dance Presentation of Pintados (tattooed) Festival and the "Pagrayhay" during the Grand Parade. The Festival of Festivals of Leyte Kasadya-an (merry-making) is an occasion that portrays the unique culture and colorful historical background of Leyte. As modernization invaded, traditional manner of tattooing and the worshiping of spirits on earth have eventually disappeared [23].

The municipality of Compostela drops the Caballo (horse-riding) Festival in honor of its Patron Saint James the Apostle for the adaptation of the one-town-one product (OTOP) eco-tourism drive of Cebu Province for a livelihood product, "Queseo" or cheese from processed carabao milk [24].

Kaamulan (tribal convergence) Festival of Malaybalay, Bukidnon has retained its traditional celebration of thanksgiving through its dances and activities that showcase the richness and identity of the culture of Bukidnon. The Kaamulan Festival serves as a unification effort for the people of Bukidnon and is a symbol of the tribe people's quest for identity and meaning over the decades [25].

Sinulog dancing in Cebu City is understood as the outcome of a highly localized urban history. Ness examines the ways in which significant aspects of Cebuano culture, such as impermanence, fluidity and the importance of using space in an optimal way in a crowded city, are embodied in the various versions of the dance [26]. The Sinulog dance is exceptional in that it serves both educational function, especially in the involvement of students, as well as the consumerist function [27].

Without an appreciation and respect for such unique and beautiful remaining traditions, the fate of traditional music and dance risks the path in other aspects of the indigenous culture that have slipped away in the face of globalization [9].

\subsection{Objectives of the Study}

This study analyzed the evolutionary transition of the Sinulog-based dance in Cebu, Philippines. It also sought to answer these objectives: (1) contrast the traditional Sinug Dance and the contemporary Sinulog-based dance in terms of the dance steps, music, ritual, costumes, and the reason or purpose of dancing; (2) identify the effects of the changes in the Sinulog-based dance in the tourism industry of Cebu City as a whole; and (3) generate a theory which serves as framework of the evolutionary transition of the Sinulog-based dance. 


\title{
2. Materials and Methods
}

\section{Research Design}

This utilized a collective case study design of the informants' narratives of their knowledge on both the traditional and contemporary Sinulog dances. A collective case study design selects an issue or concern, with multiple cases to present the selected issue in multiple perspectives [28] A Case study provided a valuable presentation of real-life situation of these two dances through the use of naturalistic observation and interviews.

\section{Research Tools}

Data were collected through interview transcripts from the selected key informants who were selected with consent. Videos and taking pictures were used to record the actual demonstration of the traditional dance using a systematized naturalistic observation, with consent by the key informants. Purposive sampling of the identified key informants, through predetermined criteria, was also utilized. There were five (5) key informants of the study who were knowledgeable and a mixture of witnesses of the traditional Sinug dance as well as the contemporary Sinulog like museum curators, and dance choreographers. There was an interview guide, audio recorder, camera, and transcribing materials used to gather data, along with the researchers' observations as field notes, and the photos captured during the actual dancing demonstrations.

The contemporary Sinulog-based dance competition was demonstrated at the stage of Cebu City Sports Center during the 2017 Sinulog Celebration; while, the traditional Sinug dance was demonstrated at the Casa Gorordo Garden in front of the Casa Gorordo Museum. The dancers of the traditional Sinug dance were formally invited with consent from the residents of Sitio Sinulog, Barangay Mabolo in Cebu City, Philippines.

Lamnek's qualitative content-reductive analysis was used in interpreting the collected data. All of the answers from the interview were transcribed accurately based on what was recorded in the audio recorder. The researchers took down important notes that were summarized and paraphrased from the transcribed data and identified and categorized themes from the noted points. These were done to all the transcripts generated. The categories or themes were checked to make sure that they are aligned with the transcripts. Those thoughts that were similar were fused into a single idea. The researchers reviewed the categories or themes once again if it fitted the original transcripts to make sure that the categorization was accurate. The researchers then presented their viewpoints and combined relevant passages based on the interview, forming a new theory on the Sinulog dance transition.

\section{Results and Discussions}

\subsection{Traditional Sinug Dance and the Contemporary Sinulog-based Dance in Contrast}

\author{
History of the Traditional Sinug Dance-Ritual
}


Worshipping through dances may have started during the pre-Hispanic era where Filipino natives give reverence to wooden idols called anitos, which they imitate the movement of nature such as the movement of the water currents in various bodies of water. This practice fits the animistic life of the Filipinos back then in the $13^{\text {th }}$ centuries. The arrival of the Spaniards brings an obliteration of tribal animism when they introduce Christianity. In Cebu, the "Sugbuanons" [Cebuano natives] imitate the river water current known as "sug," hence, the word "Sinug dance has been derived." KI3 said to have another version of the term "Sinug," which came from a "sunog nga bata" (burnt statue of a child) which is the black Señor Santo Niño, after this was found inside a burnet hut when the village of Cebu was burned by the natives as a manifestation of disgust and anger of the Spaniards. The finding of this burnt child is known as "kaplag," by Juan Camus in April 28, 1565.

Legend says that there was a fisherman who kept on catching a burnt wood locally known as "agipo." He threw the wood back to the sea but the burnt wood was always caught by his net. Eventually, he placed the burnt wood in his banka (boat) and miraculously, the number of fish he caught increased in number. Mysteriously, the burnt wood became the image of Señor Santo Niño. From that time, since the information spread, the native Cebuanos believed the Holy Child as a great provider. They danced the Sinug, carried this tradition, and passed on through centuries of Cebuano generation.

\subsubsection{Sinug Traditional Dance Steps}

The Sinug dance steps are derived from the movement of the river waves, imitating the old folks' dance steps for their anitos (wooden idols), the moment they worship. KI5 lamented that the dance is similar to the river waves of a forward-and-backward motion. Just like our lives, we experience our ups and downs. After the arrival of the Spaniards, the natives do not have a hard time adapting Christianity since their catechism and the indigenous animistic religion are similar.

The natives are instructed to stop their worship of the anitos and, instead to replace these with the Señor Santo Niño or else defying this order they would experience burning into the stake alive. Their Sinug dance ritual is not changed. In some parts of the Philippines, the Sinug has been dubbed as a "moro-moro," a war dance between the Christians and the Moros [marauding

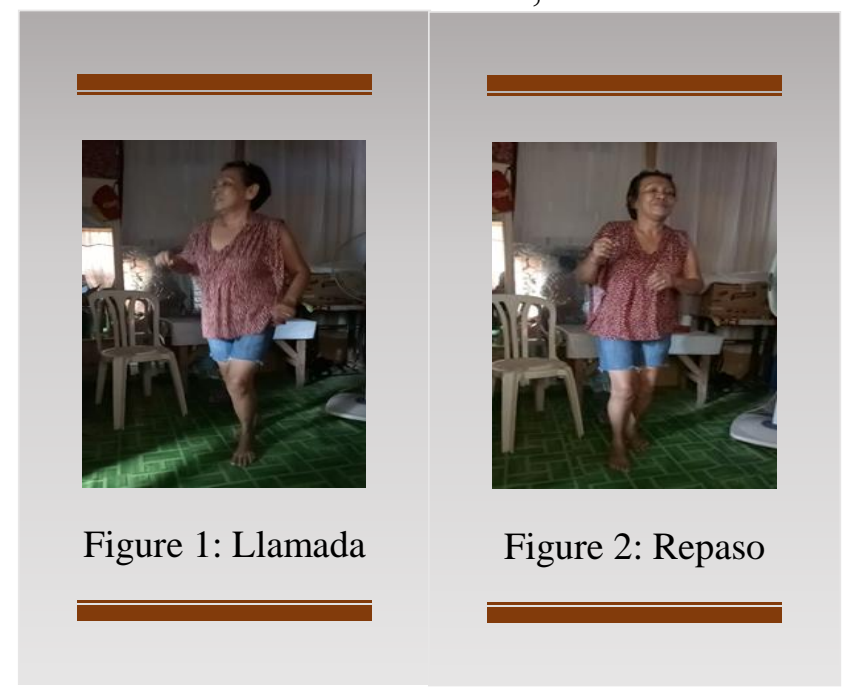
pirates in $13^{\text {th }}$ to $14^{\text {th }}$ centuries]-a symbolic gesture that the Señor Santo Niño protects the Cebuanos from harm and other forms of destruction, hence they place His Holy icon in an altar and offer Him the traditional Sinug dance, with dance steps imitating the typical war dance. 
"Ang Sinug sayaw sa pag-ampo." (The dance is really a prayer dance). Mura man gud na siya ug sayaw sa gubat." (As if, it is like a war dance.) (KI4)

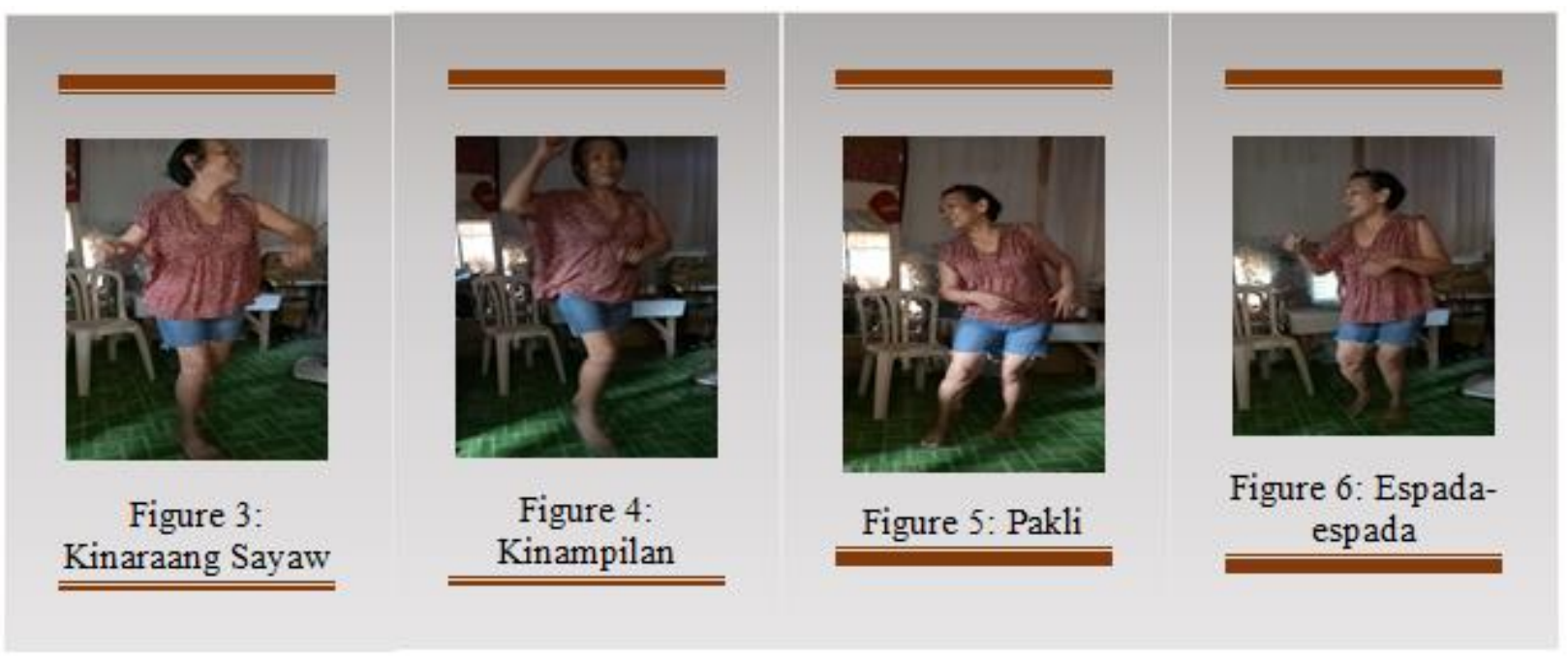

Through a naturalistic observation and with the encounter of the surviving relatives of the bearer of the old Sinug (Nang Titang Diola), the traditional Sinug follows a specific pattern of steps and rituals. The dances include seven steps that correspond to specific actions: Llamada, Repaso, Kinaraan nga Sayaw, Kinampilan, Pakli, Espada-espada and Balituk as captured in photographs with permission and consent of the niece of Nang Titang, the Beat Keeper of Sinug, as one of the key informants. "Llamada" or the assembly, as shown Figure 1, is characterized with the rolling of the drum. This is where the dancers are being called to assemble by strongly hitting the drum once, and it signals them to be ready. "Repaso," as shown in Figure 2, is the marching of the dancers to form three (3) columns in this order as the group of Muslims, Christians, and Moros. The Señor Santo Niño is placed on the table where flowers and candles are being used as decorations, i.e. called patente (improvised altar), as shown in Figure 8. "Kinaraan nga Sayaw" or the traditional dance, as shown in Figure 3, is the Sinug dancing while the Sinug beat is being played. This step is characterized with two (2) steps forward and one (1) step backward, which is typical in a Sinulog-based dance at present. "Kinampilan" or armed-with-bladed-weapon, as shown in Figure 4, is another basic step of the Sinug, which is characterized with one (1) step forward of the right foot and one (1) step backward, while the left foot remains in place. "Pakli" or flipping, as shown in Figure 5, is the bending of the hand to the opposite elbow away from the body. "Espada-espada" or sword-like-fighting, as shown in Figure 6, is the dance with the use of swords preparing for the actual battle. "Balituk" or rolling to tumble, as shown in Figure 7, signifies the end of the dance ritual.

Upon leaving the karo (carriage) from the Basilica Minore del Santo Niño, at exactly 2 o'clock in the afternoon, during his fiesta celebration, we dance the Sinug facing the karo; while dancing backwards, the people serve as a barricade (KI1). Back then, the Santo Niño was placed on the altar (patente) with candles and floral ornaments. Candle vendors also dance the Sinug using candles as offerings (KI5). 


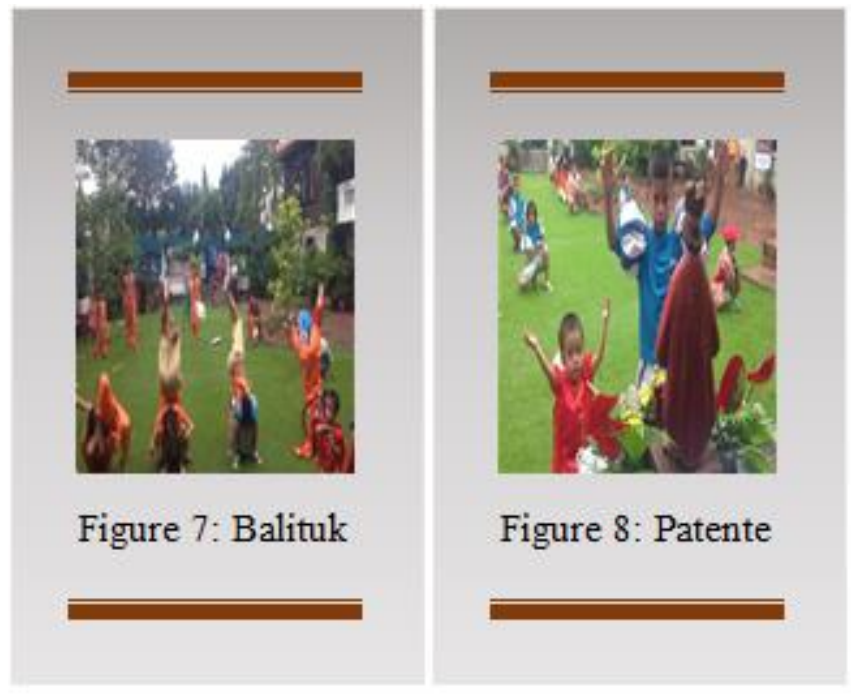

\subsubsection{Sinug Traditional Music}

In playing traditional Sinug music, a drum i.e. made of goatskin is used: the upper part of the drum is made of a male goatskin, while the other side is made of a female goatskin. The male goatskin side is used dominantly for the playing for the traditional music. Different sides create distinct sounds that are paramount in the traditional musicality of the Sinug. This indigenous musicality nuances the natives' dependency with nature and their animistic tradition.

\subsubsection{Sinug Traditional Rituals}

During the Sinug dance, there are intended intervals for rituals. First, when the dance stops, they pray in Latin and they do the offering. KI1 said that the first ritual is called Alabasyon or an introductory ritual as shown in the English version in Table 1.

Table 1: The Translation of the Cebuano Alabasyon to English

\section{Cebuano Version}

Ang alabasyon, usa ka pangadyi sa paghangyo sa Ginoo. Inig alabasyon, naay bata muduol katong Niño-niño namu mulabay siya unya muingon ug: "Matam-is nga Bathala, Bathala nga pinalangga, maanindot, maambungan nga Bata, makabibihag sa huna-huna. Bililhon labi sa Mutya. Among dungog ug himaya kalipay ning among yuta. Kalipay na dili mapala. Ang imong mahal na larawan amo nga ginahalaran ug maoy mahimong tuburan sa among mga kapalaran. Kadaot ug katalagman. Giiway mo ning kapupud-an. Busa ikaw ang among ginalauman sa among mga gikinahanglan. Busa, walay sukod sa paglaum. Kining imong mga ulipon nga sa gihapon imong pagabawion."

\section{English Version}

The introductory ritual, a form of prayer in pleading for God. During the ritual, there is child, dressed like a Señor Santo Niño, who will come and pass by to utter this prayer:

"Most Sweetened God, Most loving God, Adorable and Amiable Child, Magnetizes our Mind, Most Precious Diamond. Our Honor and Glory, Joy in our lands. Everlasting Joy. Thy Lovely Picture, we Adore and this becomes the Well-spring of our hope. Destruction and calamities, You set us free in this island. Then, You are the Refuge of our needs. Then, immeasurable love You bestowed on us. We, Your servants, will be in your fold once more." 
"Mao nay alabasyon. Ang bata ang mustorya ana. Mu-atubang ang bata ni Señor Santo Niño. Magbarog na siya silbing nihangyo na siya sa Diosnong Bata (KI2)."

(This is the ritual-prayer when asking something to God. During this ritual, the kid dressed like a Señor Santo Niño, approaches the altar and chants the aforementioned prayer in Cebuano Alabasyon. He keeps standing, asking, and pleading in front of the Holy Child.)

The Alabasyon is performed after the Repaso. Right after Alabasyon, a litany in Latin is being sung. Throughout the three (3) basic dances of Sinug (Kinaraan nga Sayaw, Kinampilan, and Pakli), there is a chanting of prayers for the names that are placed in the altar for the Señor Santo Niño intentions. This is another form of ritual performed in the traditional Sinug dancing.

\subsubsection{Sinug Traditional Costume}

According to KI2, the traditional Sinug is a war dance portraying the Christians and Filipino natives fighting in front of Señor Santo Niño. The dancers wear vest for Magellan and his men who are members of the Spanish armada, vest, crown, orb, sword, and sash for child who acts as the Señor Santo Niño, and Muslim costumes for the Moro group, and the native costumes for the Cebuano natives. These costumes showcase the typical scenario of a war dance, as one of the depictions of the war between the marauding Moro pirates and the Cebuano natives with the intervention of the Spaniards who brought Christianity to the island. The presence of Señor Santo Niño, who is brought by the Spaniards to the natives, nuances good tidings to bring peace and unity in the island, and the rest of the archipelago.

\subsubsection{Importance of Sinug}

When asked about the importance of the Sinug, all of the key informants say that the war dance as portrayed in the tradition Sinug, reminds our cultural Pacific island identity to protect our territorial domains, as a symbol of our nationalism or pride of place. Aside from its historical significance, the culture of praising Señor Santo Niño through dancing the Sinug is an imprint of our religious Christian identity that only remains dominant among the rest in Asia.

\subsection{The Contemporary Sinulog-Based Dance}

The transition of the traditional Sinug to the contemporary Sinulog is brought by people's mobility from island to island or from countries to countries. The modern Sinulog starts with the idea of the Ati-atihan festival (depicting the black Atis as the aborigines) in Kalibo, Aklan, Philippines where dancers tint their bodies with grease and turn this to black depicting the black image of Señor Santo Niño. However, 'the priest in Aklan, familiar with the Ati-atihan, was transferred in Carmen, Cebu and there he introduced the beating of the Ati-atihan musicality and dance steps to the original Sinug which was overshadowed a bit in time, paving the way to a new version of the contemporary Sinulog' (KI3). The traditional Sinug has continued to surpass the tests of time with a small family of 'Nang Titang Diola,' who unceasingly continue to lead dancing it until the last breathe of her life. However only a few committed individuals and organization try to preserve the tradition. From the traditional dance which is dancing before the "karo" or carriage with Señor Santo Niño every Friday, it develops into a grandiose festival that involved the entire Cebuano community. The idea and the administration of a festival are 
introduced by former Mayor of Cebu City, Florentino S. Solon in the 80s, which is now called the Sinulog Festival.

Val San Diego, a known Cebuano choreographer, introduces the modern steps of the Sinulogbased dance. With elaborate Castillan regalia, dancers participate in dancing the Sinulog in a non-stop Mardi Grass of street dancing along the busy streets of Cebu City's downtown and uptown areas. To date, the Sinulog Dance Festival has been clustered into two categories: the Sinulog-based and the Free Interpretation. The Sinulog-based category emphasizes dancing the concepts of Christianization, miracles, good fortunes bestowed by Señor Santo Niño to the natives using the formal Castillan heritage. The Free Interpretation Category focuses on the wellresearched variations of tribal dance steps and costumes in the Philippines, which are more dynamic than the Sinulog-based category.

\subsubsection{Sinulog-based Dance Steps}

Street dancing is promoted where dance steps are enhanced and choreography is made to be easily recognized. The festival is created in line with the identity of the Cebuanos. When the informants are asked about the steps, they all agree that the Sinulog-based dance at present are based on the basic or the fundamental steps. The Sinulog-based has become technologically advanced, faster and has more succession of steps compared to the traditional Sinug dance. There are still the basic steps but with alterations. KI4 emphasizes that the Sinulog-based dance is about folk dancing. There should be other folk dances included in the presentation; hence the steps are not purely Sinulog-based dance, the selected themes or concepts influence the alteration of its basic steps.

\subsubsection{Sinulog-based Music}

The Sinulog-based dance music is dependent on the choreographer's concept. There is no specific music, except the adopted "Sinulog beats," which are mixed with faster rhythmic patterns to be more alive and appealing i.e. popularly agreed as "One Beat, One Dance, and One Vision," as a theme. The instruments are still dependent to the choreographer's concept, as well as the speed and variations of musicality such as the use of choirs within this thematic context. All of these are dependent on the established criteria of the Sinulog contest organizers.

\subsubsection{Sinulog-based Dance Rituals}

The rituals expressed by the informants define the acting created and directed by the choreographers. Sinulog rituals range from depiction of the struggle of the natives between good and evil, healing of a dreaded disease, and thanksgiving of bountiful harvest in the farm or bountiful catch in fishing. Moreover, informants emphasize that the creation of concepts are amicable as long as it retains the worship aspect. Informants express that improvements are happening every year. Concepts are being developed for better scoring, in line with the criteria set by the organizing committee. 


\subsubsection{Sinulog-based Dance Costumes}

All of the informants rejoin that there are two (2) types of costumes in the Sinulog-based Dance Competition: The Maria Clara and the Rural Regalia. Both of these types of costumes depict the culture and the social status of the Filipinos most specifically the Cebuanos during the introduction of Christianization in the Philippines. The Maria Clara and the Barong Tagalog represent the culture of influential rich and famous members of the ilustrado (illustrious members of society); while the Rural Regalia represents the costumes of the Indios (impoverished members of society). The Maria Clara is a Philippine traditional costume inspired by the Spanish cultural traditional gown worn by female dancers. It describes to have consisted of a long loose, long-sleeved blouse, with an ankle-length skirt, and a formal pair of dancing shoes or sandals. For the male, the traditional Barong Tagalog, which consists of formal black leather shoes, formal black trouser, and a long sleeved-barong, i.e. made of "pinya" or pineapple fiber or other indigenous or a mixture of synthetic materials. The Rural Costumes depict the provincial, highland and lowland areas of Cebu, far away from the "poblacion" or the citycenter. This is characterized with farming, fishing, and vending costumes depicting on the identified town's labor force in the conceptualization of the dance. Despite these aforementioned costumes, its usage still depends with choreographer's entire conceptualization.

\subsubsection{Importance of Sinulog-based Dance}

Some considered dancing as a practice that they have been doing since then. They want to continue dancing as a way of maintaining the practice so that this would not be forgotten. Some key informants have seen the dance slowly being disremembered, since only a few dancers are dancing folk dances these days. Other informants have said that the Sinulog-based dance is an avenue for generating tourists since Sinulog Festival is known internationally, and the Sinulog dancing competition is one of its festival highlights. KI2 expresses that the Sinulog-based dance is more of a competition for a monetary award rather than giving a reverence to Señor Santo Niño.

Furthermore, other informants say that the dance is an act of offering, praising and praying of devotion to Señor Santo Niño. This shows the Cebuanos' strong belief to the Señor Santo Niño, in recognizing the almost five centuries of Cebuano Christian-Catholic heritage (1565-2017). This infers that the informants have a variety of answers with regard to the importance of Sinulog-based dance competition. Some say that dancing the Sinulog is carrying on the long centuries of Christian-Catholic tradition. Others emphasize in generating tourists while doing the competition, and some highlight the celebration in reverence to Señor Santo Niño, as a protector of life.

\subsection{Effects of Sinulog in the Tourism Industry}

The development of the Sinulog-based dance resulted in the continuous growth in the tourism industry of Cebu City, and the Philippines, as a whole. The increase of tourist arrivals every year is indicative based on the innovations of the Sinulog dance presentations such as the: grandiose execution and production of props. Some added activities in the festival include the search for 
the Festival Queen, Puppeteers Competition, Visual Merchandising Contest, Photo Contest, Short Films and others. Because of this, the informants lament that the Sinulog-based dance has already become a playground demonstration, since the necessity to provide entertaining presentations has risen every year, where we forget the basic and essential from the traditional Sinug dance. Moreover, informants do not see anything wrong with the dance presentation being highly modernized because this has become the emerging livelihood of the Cebuano couturiers, designers, choreographers, dancers, and make-up artists. Key informants also expressed that tourists want cultural tourism, i.e. authentic and unique, and they see the commercialized Sinulog-dance presentations as a composite Cebuano culture that tries to blend modern and indigenous elements.

\subsection{Theory of Cultural Transition}

With the evolution of the Traditional Sinug Dance to the contemporary Sinulog-based Dance, a Theory of Cultural Transition emerges to surface, based on the results and findings of the study. This theory conveys that culture of Sinug dancing is customarily dynamic to create its alterations that pave the way to the contemporary Sinulog dancing. However, certain factors disturb this development, which resulted in the disarray of cultural preservation and conservation on which version of the dance to be supported, either the Sinug or the Sinulog. This gives emphasis that a particular aspect of culture is being affected and reformed in relation to the favorable demands of external factors. The theory stresses that the people living into the affected culture simply adapt to the changes and create a new culture where the traditional aspects are detrimentally affected and are in danger of being forgotten.

These external factors that affect the transition of the Sinulog Dance in the face of modernization, as a particular aspect of culture are characterized by these: (a) necessity; (b) commercialization; (c) education and; (d) modernity and flexibility of time. These factors are linked with each other causing systemic changes to the entirety of a culture. Culture is evolving at all times. Moreover, material and nonmaterial cultures are affected by the introduction of new things to the society [6]. To wit, cultures change when recently developed things begin new ways of living and when new ideas take part in a culture, as it happens in the modern day Sinulogbased dance. In addition, the intertwining of urban and rural culture, the modern and traditional, the global and local is the basic characteristic of our social and cultural reality, in which modern and traditional social values are being mixed which lead to democratic progress, tolerance and acceptance of cultural distinctions as values which should be kept and promoted [8]. Thus, this is the process, which in the context of global and cultural changes, significantly influences the formation of our daily reality.

\section{Necessity}

Since culture is always evolving, the needs and wants of the people are also in constant change. Due to these inevitable vicissitudes, people have adjusted their lifestyle to fit the demands of change, thus the Sinulog Dance cultures of the Cebuanos should never be an exception. 


\section{Commercialization}

When culture is changed because of necessity, commercialization of culture follows. Commercialization indicates that authenticity of a particular aspect of culture is being affected detrimentally in relation to the favorable demands of an external factor. Because of the systemic changes caused by commercialization, an aspect of culture (say, tradition) is most likely being eradicated (as the case of the traditional Sinug dance) and the newly established significance prevails in the case of business opportunities.

\section{Education}

People can learn culture through education or experience. Systemic changes happen because of educating people and experiencing with the unauthentic. By this, what is taught or seen may be handed to the next generation; but, this does not provide assurance whether or not people should keep this at present or they eradicate this because of less value as time goes by. This is a prevalent consequence-the prize of being educated, we learn to give up and adopt new possibilities, i.e. eradicating the old and embracing the new! The essentialist notion of preservation of the traditional Sinug dance remains a heritage that museums have the right to exhibit its material remnants and the school has the right to teach the old dance steps; but this contradicts the progressivist view that nothing remains constant, everything is bound to change that shows the Sinug dance transition to what it has transcended, as the Sinulog-based dance today.

The traditional instrument of a drum made of goatskin in the Sinug dance-ritual symbolizes the animistic beliefs of the pre-Hispanic Cebuanos. As time passes by, Christianity abhors animistic worship and forms an added education that eradicates the use of the traditional drum. Because of our educational level of awareness, people learn the concept of obsolescence or wear-and-tear factor that natural materials like the goatskin undergoes this process. Goatskins are said to be durable; however, because of the moisture, pressure applied in Philippine tropical climate, and the frequent usage of the drum, cannot withstand the tests of time. Since there is a high demand of goatskin for more frequent use, it increases its supply. Hence, this sacrifices the need for more goats to be slaughtered-an obvious violation of animal rights. At present, there is already a variation of instruments and the drums used are already modernized where no trace anymore for animal sacrifices. Modern materials are already used where it is more durable and produces a wide variation of beats and sounds.

\section{Modernity and flexibility of Time}

The crucial part living in a traditional society in a modern world is to live with it. Almost everything is modern and will get even modernized as the years go by. Modernity happens when there is a need to bring the system of living of the people up-to-date. This is why there are present-day eras to separate from the past and to move forward-to make progress. There is already a creation of a new culture where the tradition has already been slowly forgotten. The illustration of the tradition and the modern intertwines the changes it faces because of the factors of cultural transition, which are visible issues in the Sinulog-based dance competition. There is already a new culture being introduced i.e. said to be in line with the tradition; however, the 
authenticity of the tradition has been challenged by these factors. It can be inferred that tradition and modernization are now linked with each other; yet, one is being compromised. What is more tragic to say is that the latter might take the place of the former if no limitations are being set where it could go beyond the line of which one is the most authentic?

\section{Conclusions \& Recommendations}

The Sinulog-based dance competition signified as the most significant activities in the entire celebration of the Sinulog Festival of Cebu City, Philippines. The transition of the traditional Sinug dance to the contemporary Sinulog dance was ignited by the change of these external factors such as: necessity, commercialization, education, and modernity and flexibility of time. The traditional Sinug dance was on the brink of extinction without the help of certain individuals and organization who took part in preserving this potential cultural heritage, as a response to the essentialist challenge posed to the curators and cultural heritage advocates. The contemporary Sinulog dance transcended to a new culture after Sinug dance was obliterated to a more progressivist view of change to increase attention of tourist attraction catapulted a more commercialized endeavor for tourism and business development. Thus, encouraging people to continue this cultural heritage of Cebu and to challenge the essentialists to protect and preserve the vast heritage of the war dance culture as depicted in the traditional Sinug dance, as one of the national cultural treasures is encouraged. Hence, the contemporary Sinulog dance advocates may also continue to find more researches to improve the inclusive growth of the dance festival. The organizers of the Sinug dance may continue the tradition and assert its relevance extensively to the tourism industry for cultural heritage development.

\section{Acknowledgements}

Due acknowledgements are given to the Dean of the College of Arts and Sciences for allowing the researches to conduct this study within the scope of the Departments of Tourism Management and the Social Sciences. Likewise, due acknowledgement is also given to Dr. Filomena T. Dayagbil, president of Cebu Normal University for encouraging and maintaining the research cultures of the university till the end of its publication and dissemination.

\section{References}

[1] Emboscado, Olan (September 01, 2014). "KAAMULAN FESTIVAL 2014: ONE HUNDRED YEARS OF CULTURAL LEGACY." Available at http://thetravelteller.com/kaamulan-festival2014-one-hundred-years-of-cultural-legacy/

[2] Carretero, Matthew Despi (2008). "REDEFINING AND RETRACTING HISTORY: THE SORSOGON MUSEUM AND ITS PROCESSING OF MEMORY THROUGH ITS COLLECTIONS." Available at http://documents.mx/documents/redefining-and-retracinghistorythe-sorsogon-museum-and-its-processing-of-memory-through-its-collections.html

[3] Uy, Rodson (2016). "SINULOG 2016: A MODERNIZED FESTIVAL." Available at https://pressmanchronicles.wordpress.com/2016/02/07/sinulog-2016-a-modernized-festival/

[4] Harvey, Bruce. (2011). "WHY CULTURAL HERITAGE MATTERS." 120 Collins Street, Melbourne Victoria, 3000, Australia. 
[5] Chirkov, Valery (2016). "FUNDAMENTALS OF RESEARCH ON CULTURE AND PSYCHOLOGY: THEORY AND METHODS." 711 Third Avenue, New York, NY 10017: Routledge.

[6] OpenStax College, "INTRODUCTION TO SOCIOLOGY." OpenStax College. 21 June 2012. <http://cnx.org/content/col11407/latest/>.

[7] Shahzad, M., Shahzad, M.N., Fatima, S., Hussain, S., Ahmed, T. (2015). "IMPACT OF MODERNIZATION AND CHANGING TRADITIONAL VALUES OF RURAL SETUP IN DISTRICT KHUSHAB. The Explorer Islamabad: Journal of Social Sciences, Volume 1, 2015.

[8] Petkovic, Jelena (2007). Traditional Values and Modernization Challenges in Forming Urban and Rural Culture. Facta Universitatis. Available online at http://facta.junis.ni.ac.rs/pas/pas2007/pas2007-02nn.pdf

[9] Browning, Megan, "A Study of Traditional Dance and Drumming in Tanzania with the African Traditional Dance Group" (May, 2009). SIT Tanzania Wildlife Ecology and Conservation.

[10] Ekka, Nancy, "Impact on Modernization on Tribal Religious Customs and Traditions: A Case Study of Rourkela" (May, 2013). Master of Arts in Development Studies, Department of Humanities and Social Sciences.

[11] United Nations Educational, Scientific and Cultural Organization (2015). Performing Arts (such as traditional music, dance and theatre). Intangible Cultural Heritage. Available at http://www.unesco.org/culture/ich/en/performing-arts-00054

[12] Core of Culture (2014). Endangered Dance by Dr. Sangita Shresthova. Available at $\mathrm{http} / / / \mathrm{www}$.coreofculture.org/what-is-endangered- dance.html

[13] Encyclopedia of American Studies, ed. Miles Orvell (Baltimore: Johns Hopkins University Press, 2011), s.v. "Dance" (by Luke C. Kahlich), http://eas-ref.press.jhu.edu/view?aid=229 (accessed December 28, 2011).

[14] Kim, Min (2011). Dancing Between Tradition and Modernity: Colonization, Westernization, and Identity in Korean Dance During the Japanese Colonial Period. Available online at http://iafor.org/archives/offprints/acah2011-offprints/ACAH2011_0117.pdf

[15] Penn, Melissa, "Uncovering the Essence of Flamenco: An Explanation of Pure Flamenco versus Nuevo Flamenco" (n.d.) Music 150: World Music.

[16] Bedinghaus, Treva (March, 2016). What is Flamenco Dance? Available at http://dance.about.com/od/typesofdance/p/Flamenco.htm

[17] Rai, Dik Bahadur, "The impacts of Modernization on the traditional Sakawa Sili festival in the Rai Kirat community of Nepal: A case study of the Rai community" (Autum, 2012). Master in Philosophy in Indigenous Studies Faculty of Humanities, Social Sciences and Education.

[18] Sanga, Daines (2013). TRADITIONAL DANCES AND BONGO FLEVA: A STUDY OF YOUTH PARTICIPATION IN NGOMA GROUPS IN TANZANIA." Available online at http://www.qucosa.de/fileadmin/data/qucosa/documents/13746/SF_20_Sanga.pdf

[19] Madiova, Marilyne Antonette, "MUSIC, DANCE, AND NEGOTIATIONS OF IDENTITY IN THE RELIGIOUS FESTIVALS OF BICOL, PHILIPPINES" (2014). Doctor of Philosophy (Music: Musicology), University of Michigan.

[20] Carretero, Matthew Despi (2008). "REDEFINING AND RETRACTING HISTORY: THE SORSOGON MUSEUM AND ITS PROCESSING OF MEMORY THROUGH ITS COLLECTIONS." Available at http://documents.mx/documents/redefining-and-retracinghistorythe-sorsogon-museum-and-its-processing-of-memory-through-its-collections.html

[21] Calopez, Christopher G, et al. (2011). "THE ATI-ATIHAN FESTIVAL: ITS IMPACT TO THE ECONOMY AND TOURISM INDUSTRY IN KALIBO, AKLAN.” National Peer Reviewed Journal JPAIR Multidisciplinary Journal, Volume 4, May 2011.

[22] Allford, Scott (2010). "ATI-ATIHAN EXPERIENCE. TOURISM PHILIPPINES: UNBIASED UPDATED TRAVEL INFORMATION.” Available at http://tourism-philippines.com/ati-atihanexperience/ 
[23] Philippine Country (2006). "TACLOBAN PINTADOS FESTIVAL." Available at http://www.philippine-tourism.biz/biz/tacloban-pintados.html

[24] The Freeman (June 2013). "QUESEO FESTIVAL DE COMPOSTELA," Cebu. Available at http://www.philstar.com:8080/cebu-lifestyle/2013/06/15/954250/queseo-festival-de-compostelacebu

[25] Doon Po Sa Amin Team (2017). "FIVE FACTS ABOUT THE KAAMULAN FESTIVAL OF BUKIDNON.” Available at http://doonposaamin.ph/articles/activities-to-enjoy/5-facts-about-thekaamulan-festival-of-bukidnon

[26] Kringelback, Helene Neveu \& Skinner, Jonathan (2014). "DANCING CULTURES: GLOBALIZATION, TOURISM AND IDENTITY IN THE ANTHROPOLOGY OF DANCE." Berghahn Books.

[27] Valeros, Maria Eleanor E. (2012). "SINUG OR SINULOG?" Available at http://www.philstar.com/cebu-lifestyle/773978/sinug-or-sinulog

[28] Creswell, John W. (2007). "QUALITATIVE INQUIRY \& RESEARCH DESIGN: CHOOSING AMONG 5 APPROACHES. Thousand Oaks, California: Sage Publications, Inc.

*Corresponding author.

E-mail address: inocian03@yahoo.com 